\title{
HIV, infant feeding and more perils for poor people: new WHO guidelines encourage review of formula milk policies
}

\author{
Anna Coutsoudis, ${ }^{a}$ Hoosen M Coovadiab ${ }^{\text {\& }}$ Catherine M Wilfert ${ }^{c}$
}

\begin{abstract}
The release of the new WHO guidelines on HIV and infant feeding, in a global context of widespread impoverishment, requires countries to re-examine their infant-feeding policies in relation to broader socioeconomic issues. This widening scope is necessitated by compelling new reports on the scale of global underdevelopment in developing countries. This paper explores these issues by addressing feeding choices made by HIV-infected mothers and programmes supplying free formula milks within a global environment of persistent poverty. Accumulating evidence on the increase in malnutrition, morbidity and mortality associated with the avoidance or early cessation of breastfeeding by HIV-infected mothers, and the unanticipated hazards of formula feeding, demand a deeper assessment of the measures necessary for optimum policies on infant and child nutrition and for the amelioration of poverty. Piecemeal interventions that increase resources directed at only a fraction of a family's impoverishment, such as basic materials for preparation of hygienic formula feeds and making flawed decisions on choice of infant feeding, are bound to fail. These are not alternatives to taking fundamental steps to alleviate poverty. The economic opportunity costs of such programmes, the equity costs of providing resources to some and not others, and the leakages due to temptation to sell capital goods require careful evaluation. Providing formula to poor populations with high HIV prevalence cannot be justified by the evidence, by humanitarian considerations, by respect for local traditions or by economic outcomes. Exclusive breastfeeding, which is threatened by the HIV epidemic, remains an unfailing anchor of child survival.
\end{abstract}

Bulletin of the World Health Organization 2008;86:210-214.

Une traduction en français de ce résumé figure à la fin de l'article. Al final del artículo se facilita una traducción al español. . التزجمة العربية لهذه الخلاصة في نهاية النص الكامل لهذه المقالة.

\section{WHO Consensus Statement on HIV and Infant Feeding}

The new WHO Consensus Statement on HIV and Infant Feeding ${ }^{1}$ highlights critical issues in the continuing debate on whether the HIV transmission resulting from breastfeeding can ever be superseded by the benefits of breastfeeding and therefore justified ethically. Some of the new findings that are referred to in the document include: (1) exclusive breastfeeding for up to 6 months was associated with a three- to fourfold decreased risk of HIV transmission compared to non-exclusive breastfeeding in three large cohort studies; (2) where free infant formula was provided, the combined risk of HIV transmission and death was similar whether infants were formula fed or breastfed from birth; and (3) early breastfeeding cessation was associated with reduced HIV transmission but also with increased risk of morbidity and child mortality in infants born to HIV-infected mothers.
These findings should encourage developing countries to reassess their positions on infant feeding for HIVinfected mothers and balance policies that support breastfeeding and formula feeding by HIV-infected mothers. Efforts to reduce mother to child transmission (MTCT) of HIV by the use of antiretroviral drugs, caesarean section and formula milks have been extremely successful in industrialized countries and some middle-income countries. These experiences have resulted in implementation of programmes that promote the use of formula feeds in poor populations. There is no doubt that there are small groups in resourceconstrained countries with basic and essential services that allow the hygienic preparation of formula milks. However, for the child population as a whole the unrestrained promotion of formula is generally harmful. Many of these programmes ignore the biological, cultural, social, economic and political contexts in which breastfeeding is embedded. We therefore examine these issues from two different perspectives: first, the evidence of the impact on child health of formula feeding of babies born to HIVinfected women; and second, whether we are able to reverse poverty piecemeal through provision of household materials for hygienic preparation of formula ("formula-plus") such that formula feeding can be provided safely.

\section{Rational and sensible choices}

For the past six years, infant-feeding options for HIV-infected women have largely been governed by guidelines by WHO, the United Nations Children's Fund (UNICEF) and the Joint United Nations Programme on HIV/AIDS (UNAIDS). ${ }^{2}$ These guidelines offered women a reasonable framework in which to make choices on infant feeding appropriate to their socioeconomic

\footnotetext{
a Department of Paediatrics and Child Health, Nelson R Mandela School of Medicine, University of KwaZulu-Natal, South Africa.

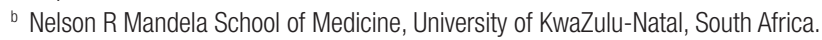

c Elizabeth Glaser Pediatric AIDS Foundation, Washington, DC, United States of America.

Correspondence to Anna Coutsoudis (e-mail: coutsoud@ukzn.ac.za).

doi:10.2471/BLT.07.041673
}

(Submitted: 21 February 2007 - Revised version received: 12 July 2007 - Accepted: 27 September 2007 - Published online: 27 November 2007) 
conditions. However, the task of weighing risks and benefits created considerable difficulties for policy-makers and for health-care workers in the field. Part of the difficulty rested on the incomplete evidence on which the guidelines were based. Emerging new data from several important studies threw more light on this area, and therefore a reevaluation appeared to be necessary and urgent. WHO convened a technical consultation on HIV and Infant Feeding in October 2006. ${ }^{1}$ A sharp edge to these issues has been added by several global reports ${ }^{3,4}$ on the immense scale and persistence of poverty that directly affects children's lives.

According to the 2000 guidelines, formula feeding is recommended for HIV-infected women who find it culturally acceptable and who are able to prepare artificial milks hygienically. This requires the basic necessities of clean home environments and water and proper sanitation. Where formula feeding is not "acceptable, feasible, affordable, sustainable and safe", HIVinfected women are recommended to breastfeed exclusively for the first few months. ${ }^{2}$ The major point we wish to stress in the discussion on formula feeding or breastfeeding is that the choice between the two must first be made on scientific evidence.

We present data on the importance of breastfeeding for poor HIV-infected women. The recent Lancet Child Survival series ${ }^{5}$ reinforces the overriding importance of breastfeeding even in HIV-endemic countries; promotion of exclusive breastfeeding was estimated to prevent $13 \%$ of current child deaths, whereas the use of nevirapine and replacement feeding would only prevent $2 \%$ of current global child deaths. This is not to choose between these two interventions, but to insist on both. The benefits of breastfeeding in terms of reducing infectious disease mortality in developing countries have been well documented and have been reinforced in a recent meta-analysis. ${ }^{6}$ In addition, secondary analysis of data from a multicentre study in three developing countries revealed that non-breastfed infants had a tenfold higher risk of dying when compared to predominantly breastfed infants. ${ }^{7}$ Apart from preventing infectious disease mortality, breastfeeding for the general population carries multiple short- and long-term advantages. ${ }^{8}$ Human breast milk contains a large variety of factors; this provides some explanation for the immunological mechanisms underlying the protective benefits of breast milk against enteric infections as well as chronic diseases later in life. ${ }^{9}$

Next we consider the impact of formula feeding for infants of HIVinfected women in the developing world. Fortuitously (given the support for "formula-plus" programmes from experiences in Haiti), evidence is available from a comprehensive programme ${ }^{10}$ on the impact of replacing breast milk and of wide-scale access to formula milks, and this reinforces the points we raise. This group encouraged formula feeding within a service that assured participants a degree of programme comprehensiveness and support largely unavailable in Africa and most developing countries. This comprehensive programme included weekly clinic visits for collection of formula milk and education on safe preparation of feeds, as well as growth monitoring. In addition, formal medical assessments and appropriate treatment and care [immunizations and Pneumocystis carinii pneumonia (PCP) prophylaxis] was provided monthly up to 4 months of age, and then at $6,9,12,15,18$ and 24 months. Despite reductions in HIV transmission, extremely high infant mortality rates (217 per 1000 live births) were reported among infants born to HIV-positive women; ${ }^{10}$ importantly, $70 \%$ of these deaths occurred within the first 6 months after birth. The higher than expected mortality in infants receiving several interventions as listed above was not anticipated, but the authors did not consider formula feeding to be one of the potential factors involved in the deaths. The conclusion they came to was that "supplying formula to virtually all children would seem to exclude a strictly nutritional cause for the excess mortality". In fact, such a course of action would have almost certainly increased the mortality risks. These mortality rates were similar to those before the programme was implemented.

Further programmatic evidence is available from Botswana. Botswana, a stable, democratic, middle-income country [per capita gross domestic product (GDP) of US\$9945, compared to a figure of US\$ 1946 for subSaharan Africa], has the continent's flagship programme on prevention of
Towards a formula milk policy review

MTCT (PMTCT). Initiated in 1999, this PMTCT programme provided free formula to all HIV-infected mothers. An explosive outbreak of diarrhoea in the first quarter of 2006 gave a sobering vision of the dangers of formula feeding among populations in which breastfeeding had been the norm. At the time of the outbreak about a third of all infants under 6 months were not breastfeeding: the practice of formula feeding had "spilled-over" to the uninfected population. The Centers for Disease Control and Prevention (CDC) investigations ${ }^{11}$ reported about 35000 cases of diarrhoea resulting in 532 deaths in the first quarter of 2006 , compared to about 100 cases and only 21 deaths in the same period in 2005 . Of the patients hospitalized, 97\% had piped water; this was a situation with a clear sufficiency of basic resources. What went wrong? The largest risk factor was "not breastfeeding" (odds ratio 50.0; 95\% confidence interval: 4.5100). The dangers of formula feeding were evident in infants born to HIVinfected as well as to HIV-uninfected women, and were demonstrable despite provision of free formula and the availability of resources beyond what may be affordable for many countries.

Furthermore, we have recently been reminded that powdered infant formulas are not sterile products and may contain low levels of Salmonella ${ }^{12}$ or other contaminants ${ }^{13,14}$ and cause outbreaks of diarrhoea, even in industrialized countries. Regardless of other resources being made available, the choice of formula should not be lightly undertaken in any population.

Therefore, overall such programmes provide no measurable benefit when assessing the two risks to which these children are exposed: (1) the risk of HIV transmission through breastfeeding; and (2) the risk of mortality due to common childhood illnesses. The goal of any PMTCT programme is to keep children free of HIV infection and to reduce mortality risks. In the light of the necessity to be able to measure the balance between these two risks, the international community now encourages the use of a single index, HIV-free survival, which gives the net result of number of children who are not infected and who have survived. ${ }^{15}$ Evidence was presented at the recent WHO consultation on HIV and Infant Feeding ${ }^{1}$ which showed that in carefully controlled 
studies where free infant formula was provided the 18-month HIV-free survival was similar in infants who were replacement fed from birth and infants breastfed for 3-6 months (Botswana and Côte d'Ivoire). Early breastfeeding cessation (4-6 months) was associated with increased child mortality from 4 to 24 months in a randomized trial in Zambia. Additionally, preliminary findings from trials in Kenya, Malawi, Uganda and Zambia, where HIVexposed infants were provided with free formula to allow early discontinuation of breastfeeding, showed an increase in growth faltering and serious gastroenteritis events. ${ }^{16}$

\section{"Formula-plus" policies}

Challenges to the above WHO recommendations on infant feeding have recently appeared in the scientific literature, suggesting the provision of formula milks at lower thresholds of household hygiene and without all the WHO guidelines being met. Of particular interest is one view, partly based on experience in Haiti, which is much more vigorous. It attempts to minimize the hazards of formula among the poor by also providing direct support for the preparation of uncontaminated milk "formula plus". ${ }^{17}$ Neither the scientific basis nor the validity of field experience for this position is tenable. This position is rooted in the well-recognized philosophy that health professionals should go beyond understanding the minutiae of medicine, "molecular-level analyses of disease", and address "largescale forces" such as the social, economic and political determinants of health and sickness. ${ }^{17}$ However, the provision of formula, together with stoves, kerosene, bottles and "when possible food aid and housing assistance" to very poor communities affected by HIV is a leap from this unassailable moral and ethical high ground to policy levels of dubious social benefit based on questionable scientific evidence. Although such programmes will result in a lower risk of HIV transmission, they are likely to exacerbate morbidity and mortality rates and to aggravate the already high child mortality statistics. ${ }^{5}$

Clearly, the evidence adduced above shows something more than free formula, clean water and electricity at household level is necessary for infants to be able to receive safe formula feeds.
Providing formula feeding is unlikely to improve the poverty status of mothers; if anything, it will increase poverty levels because of the attendant morbidity and mortality risks associated with formula feeding. The risks associated with formula feeds go beyond how safely these are made up. Externally funded projects may ameliorate the situation in the short term but this may not be sustainable by national governments. The high costs of "formula-plus" could arguably be used more productively in other development initiatives, i.e. "opportunity costs”. Resources provided only to some households and not to others can increase inequities, and there will always be the temptation to sell capital goods.

A timely analogue to these infantfeeding issues is a recent study ${ }^{18}$ demonstrating that direct indices of HIV transmission risk (HIV incidence; unprotected sex) were resistant to "structural” (microfinancing) and behavioural interventions. Although these measures were able to reduce proximal contextual factors (intimate-partner violence) they had no impact on the risk of acquiring HIV. PMTCT requires both upstream measures (reducing poverty and improving household environments) and immediate prophylactic interventions (appropriate infant feeding, prophylactic antiretrovirals, safe delivery, caesarean section). The effects of the former are medium- to long-term; the impact of the latter is immediate.

\section{The scale of poverty and aid for AIDS}

Poverty impacts on child survival and the most logical solution would be to reverse this poverty. We need to face the reality that the world is cruelly, unjustly and intractably divided between rich and poor. Although there is much that we can do to alleviate poverty, these measures require time and revolutionary changes in the global milieu and reorientation of many national government policies. Poverty is not easily or quickly reversed; even the Millennium Development Goals aim only to halve the deficits in provision for sanitation by 2015 while currently a little more than a third of households in Africa have access to sanitation. The scale of the problem of poverty related to the basic necessities for life is massive, and the statistics enumerated by the Human Development Report ${ }^{4}$ are depressing.
There is a global "water crisis", with sub-Saharan Africa bearing the brunt. Lack of clean water kills five times more children than HIV/AIDS and curtails economic growth; sub-Saharan Africa loses 5\% of its GDP every year, more than it obtains through aid, due to lack of access to water and sanitation. And, central to this discussion, more than 1.1 billion people do not have proper access to clean water and 2.6 billion lack access to sanitation. The 2007 UNICEF Report $^{3}$ makes dismal comparisons between the situation in sub-Saharan Africa as compared to the rest of the world in terms of improved drinking water, adequate sanitation, primary health care services and gross national income for 2005. The under-five and infant mortality rates are twice as high in sub-Saharan Africa as compared to the rest of the world; life expectancy at birth is 46 years compared to 68 years. The Human Development Report ${ }^{4}$ identifies the measures to be taken by national governments, international agencies and communities. The report notes that the current "water crisis" is not only caused by shortages of physical supplies but is deeply rooted in "poverty, inequality and unequal power relationships". These two reports suggest that equity, fairness and the reversal of poverty are not likely to be reached in the near future. We therefore need to engage in two parallel processes: (1) developing safer infant-feeding options for infants of HIV-infected women; and (2) development and povertyalleviation programmes. The one cannot wait for the other; they need to occur as two simultaneous and interlinked processes. We are not suggesting that it is useless to try to make replacement feeding safer; instead we are calling for a reasoned decision based on the reality that social and economic development takes time. The urgency and immediacy of the problem compels us to make the best decision for addressing the problem in the present.

We face a replay of the events during the last quarter of the past century, when the global health community opposed the unethical promotion of formula by food manufacturers among impoverished populations. At the time, it was noticed that in developing countries replacement of breastfeeding with formula and other milks and foods was attended by increased mortality and weak growth and development. 
The public health implications of such replacement were so grave that they resulted in international mobilization aimed at restricting and regulating such harmful corporate practices. This campaign led, in 1981, to acceptance of an International Code of Ethics for the Marketing of Breastmilk Substitutes by WHO, and more recently to the UNICEF Baby Friendly Hospital Initiative. The end result of these global endeavours is the fostering, promotion and protection of breastfeeding. The final deliberations at the recent WHO technical consultation on HIV and infant feeding ${ }^{1}$ also recommended that governments and other stakeholders should revitalize breastfeeding protection, promotion and support in the general population, even in areas of high HIV prevalence. As pointed out by Holmes and Savage, although exclusive breastfeeding is not currently widely practiced in the developing world, this can be changed by providing mothers with skilled support from well-trained lay infant-feeding counsellors. ${ }^{19}$

\section{Conclusion}

Although formula feeding is certainly the correct choice for some HIV-positive women who meet all the criteria of the WHO guidelines, exclusive breastfeeding for the first 6 months for the majority of HIV-infected mothers who are poor reflects the optimum balance between advantages and disadvantages.

In disadvantaged settings, programmes offering formula are not easy to implement safely. Providing formula to poor populations with high HIV prevalence can neither be justified by the evidence, by humanitarian consideration, by respect for local traditions nor by economic outcomes. The conse- quences of this type of aid to low-income countries may be similar to those that have often undermined human health and development: for example, the disastrous effects due to the Structural Adjustment Policy of the International Monetary Fund and the dumping of formula on breastfeeding populations. Exclusive breastfeeding is threatened by the HIV epidemic as it has been in the past by unregulated marketing of formula in poor populations, but it remains an unfailing anchor of child survival. The new evidence and guidelines suggested by WHO underline the importance of scaling-up efforts to improve exclusive breastfeeding rates for all children to meet the Millennium Development Goals of reducing child mortality. ${ }^{5}$

Competing interests: None declared.

\begin{abstract}
Résumé
Dans le contexte mondial actuel d'appauvrissement généralisé, les nouvelles directives de l'OMS sur le VIH et l'alimentation du nourrisson récemment publiés demandent aux pays de réexaminer leurs politiques d'alimentation du nourrisson en tenant compte d'aspects socioéconomiques plus larges. Cet élargissement de la perspective est motivé par de nouveaux rapports convaincants sur l'ampleur à l'échelle mondiale du sous-développement dans les pays en développement. Le présent article étudie ces aspects en examinant les choix en matière d'alimentation du nourrisson faits par les mères infectées par le VIH et les programmes fournissant gratuitement du lait pour nourrisson dans un contexte mondial de pauvreté persistante. Les preuves qui s'accumulent d'une augmentation de la malnutrition, de la morbidité et de la mortalité liée à l'abstention ou à l'arrêt précoce de l'alimentation au sein par les mères infectées et les dangers imprévus de l'alimentation artificielle exigent une évaluation plus approfondie des mesures nécessaires pour optimiser les politiques en matière d'alimentation
\end{abstract}

\section{VIH, alimentation du nourrisson et autres risques pour les personnes pauvres : Ies nouvelles directives de I'OMS incitent à réviser les politiques en matière de lait pour nourrissons}

du nourrisson et de l'enfant et pour faire reculer la pauvreté. Les interventions fragmentaires pour augmenter les ressources qui ne compensent qu'une partie de l'appauvrissement familial (fourniture de matières de base pour préparer des aliments pour nourrissons conformes à l'hygiène par exemple) et prennent de mauvaises décisions concernant l'alimentation du nourrisson, sont condamnées à échouer. II n'existe pas d'alternative à la prise de mesures fondamentales pour atténuer la pauvreté. Les coûts d'opportunité de tels programmes, les coûts en matière d'équité de la fourniture sélective de ressources et les pertes dues aux tentations de vendre des biens en capital doivent être soigneusement évalués. La fourniture de préparations pour nourrissons à des populations pauvres subissant une forte prévalence du VIH ne peut se justifier par des éléments factuels, des considérations humanitaires, le respect des traditions locales ou des résultats économiques. L'alimentation exclusivement au sein, menacée par l'épidémie de VIH, reste la base inébranlable de la survie de l'enfant.

\section{Resumen \\ EI VIH, la alimentación del lactante y otros peligros para la población pobre: las nuevas directrices de la OMS llevan a revisar las políticas sobre las preparaciones para lactantes \\ La publicación de las nuevas directrices de la OMS sobre el VIH y la alimentación del lactante, en un contexto mundial de empobrecimiento generalizado, obliga a los países a revisar sus políticas de alimentación del lactante en relación con algunos aspectos socioeconómicos más amplios. Esta perspectiva más amplia es imprescindible a la vista de la contundencia de los últimos datos sobre la magnitud del subdesarrollo global en los países en desarrollo. En este artículo se analizan esas cuestiones centrando la atención en las decisiones de alimentación de sus hijos que toman las madres infectadas por el VIH y en \\ los programas que suministran leche artificial gratuita en un contexto mundial de pobreza persistente. La creciente evidencia de un aumento de la malnutrición, la morbilidad y la mortalidad asociadas a la evitación o la interrupción temprana de la lactancia materna por las madres infectadas por el VIH y los riesgos imprevisibles de las preparaciones para lactantes exigen una evaluación más profunda de las medidas necesarias para formular políticas óptimas sobre la nutrición del lactante y del niño y para mitigar la pobreza. Las intervenciones fragmentarias de incremento de los recursos con miras a paliar sólo una parte}


del empobrecimiento de las familias, como productos básicos para la elaboración higiénica de las preparaciones y algunas decisiones desacertadas en materia de alimentación del lactante, están destinadas a fracasar. No son ésas alternativas que puedan suplir medidas fundamentales de mitigación de la pobreza. Los costos de oportunidad económicos de esos programas, la inequidad que supone proporcionar recursos a unos y no a otros, y las pérdidas debidas a la tentación de vender los bienes de capital exigen una detenida evaluación. El suministro de preparaciones a las poblaciones pobres con alta prevalencia de infección por VIH no puede justificarse aduciendo la evidencia disponible, consideraciones humanitarias, el respeto de las tradiciones locales o los efectos económicos. La lactancia materna exclusiva, amenazada por la epidemia de $\mathrm{VIH}$, sigue siendo un arma fundamental para la supervivencia infantil.

\section{ملخص فيروس الإيدز وإطعام الرضَّع، ومزيد من الأخطار للفقراء: دلائل إرشادية

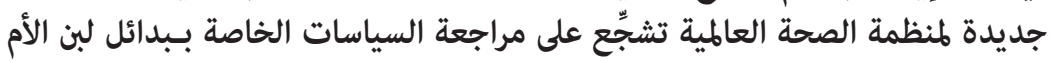

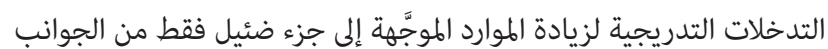

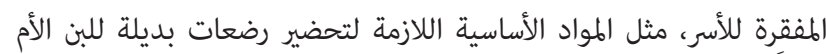

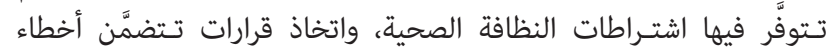

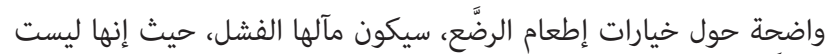

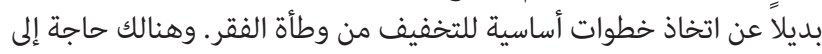

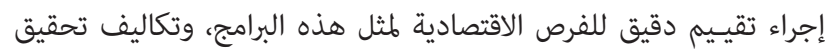

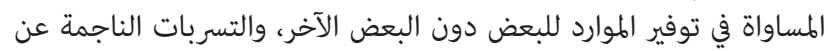

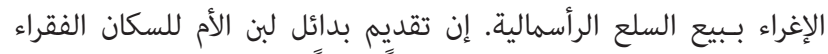

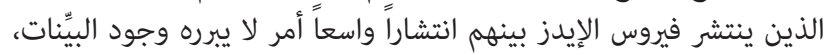

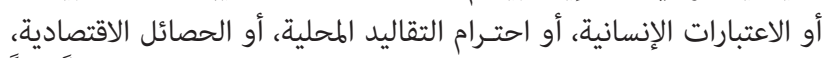
فالإرضاع من الثدي دون غيره، وهو أمر يهدِّده وباء الإيدز، يظل الإندان ملاذاً ثابتًا

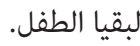

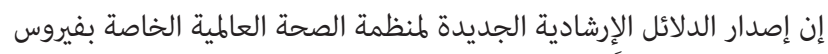

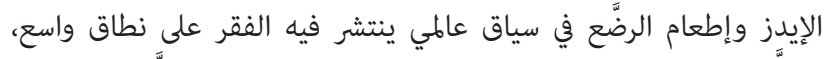

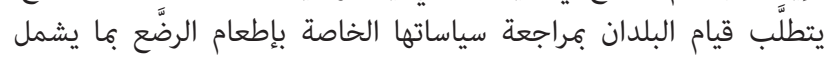

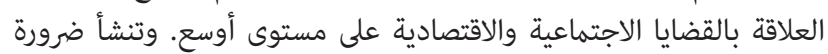

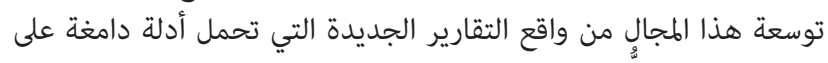

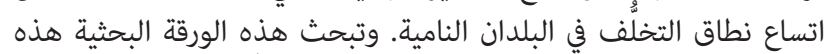

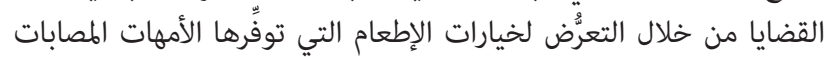

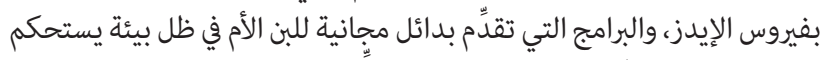

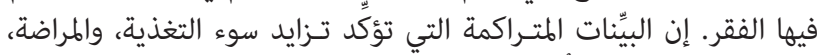

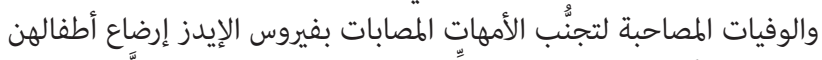

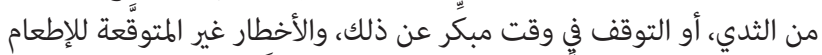

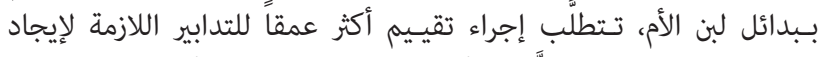

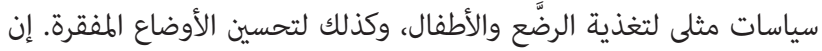

\section{References}

1. HIV and Infant Feeding Technical Consultation held on behalf of the inter-agency task team on prevention of HIV infections in pregnant women, mothers and their infants. Geneva: WHO; 2006. Available from: http://www.who.int/childadolescent-health/New_Publications/NUTRITION/consensus_statement.pdf

2. New data on the prevention of mother to child transmission of HIV and their policy implications. WHO, UNICEF, UNAIDS; 2000.

3. The state of the world's children 2007. Women and children: the double dividend of gender equality. New York: UNICEF; 2006.

4. Human Development Report 2006. Beyond scarcity: power, poverty and the global water crisis. New York: United Nations Development Programme; 2006.

5. Jones G, Steketee RW, Black RE, Bhutta ZA, Morris SS \& Bellagio Child Survival Study Group. How many child deaths can we prevent this year? Lancet 2003; 362: 65-71. PMID:12853204 doi:10.1016/S01406736(03)13811-1

6. WHO Collaborative Study Team on the Role of Breastfeeding on the Prevention of Infant Mortality. Effect of breastfeeding on infant and child mortality due to infectious diseases in less developed countries: a pooled analysis. Lancet 2000; 355: 451-5. PMID:10841125

7. Bahl R, Frost C, Kirkwood BR, Edmond K, Martines J, Bhandari N, et al. Infant feeding patterns and risks of death and hospitalization in the first half of infancy: multicentre cohort study. Bull World Health Organ 2005; 83: 418-25. PMID:15976892

8. Coutsoudis A, Rollins N. Breastfeeding and HIV transmission: the jury is still out. J Pediatr Gastroenterol Nutr 2003; 36: 434-42. PMID:12658031 doi:10.1097/00005176-200304000-00003

9. Newburg DS, Walker WA. Protection of the neonate by the innate immune system of developing gut and of human milk. Pediatr Res 2007; 61: 2-8. PMID:17211132 doi:10.1203/01.pdr.0000250274.68571.18

10. Noel F, Wright PF, Bois G, Deschamps MM, de Matteis P, Cassangnol R, et al. Contribution of bacterial sepsis to morbidity in infants born to HIV-infected Haitian mothers. J Acquir Immune Defic Syndr 2006; 43: 313-19. PMID:17079993 doi:10.1097/01.qai.0000242463.73817.c6
11. Creek T. Role of infant feeding and HIV in a severe outbreak of diarrhoea and malnutrition among young children - Botswana, 2006. Presented at the President's Emergency Plan for AIDS Relief Emergency Meeting/2006 HIV/ AIDS Implementers' Meeting, Durban, South Africa; 2006.

12. Brouard C, Espie E, Weill FX, Kerouanton A, Brisabois A, Forgue AM, et al. Two consecutive large outbreaks of Salmonella enterica serotype Agona infections in infants linked to the consumption of powdered infant formula. Pediatr Infect Dis J 2007; 26: 148-52. PMID:17259878 doi:10.1097/01. inf.0000253219.06258.23

13. Weir E. Powdered infant formula and fatal infection with Enterobacter sakazakii. Can Med Assoc J 2002; 166: 1570.

14. Threlfall EJ, Ward LR, Hampton MD, Ridley AM, Rowe B, Roberts D, et al. Molecular fingerprinting defines a strain of Salmonella enterica serotype anatum responsible for an international outbreak associated with formuladried milk. Epidemiol Infect 1998; 121: 289-93. PMID:9825779 doi:10.1017/ S0950268898001149

15. Thior I, Lockman S, Smeaton LM, Shapiro RL, Wester C; Heymann SJ, et al. Breastfeeding plus infant zidovudine prophylaxis for 6 months vs formula feeding plus infant zidovudine for 1 month to reduce mother-to-child HIV transmission in Botswana: a randomized trial: the Mashi Study. JAMA 2006; 296: 794-805. PMID:16905785 doi:10.1001/jama.296.7.794

16. Wilfert CM, Fowler MG. Balancing maternal and infant benefits and the consequences of breast-feeding in the developing world during the era of HIV infection. J Infect Dis 2007; 195: 165-7. PMID:17191159 doi:10.1086/510255

17. Farmer PE, Nizeye B, Stulac S, Keshavjee S. Structural violence and clinical medicine. PLoS Med 2006; 3: e449. doi:10.1371/journal.pmed.0030449

18. Pronyk PM, Hargreaves JR, Kim JC, Morison L, Phetla G, Watts C, et al. Effect of a structural intervention for the prevention of intimate-partner violence and HIV in rural South Africa: a cluster randomised trial. Lancet 2006; 368: 1973-83. PMID:17141704 doi:10.1016/S0140-6736(06)69744-4

19. Holmes WR, Savage F. Exclusive breastfeeding and HIV. Lancet 2007; 369:1065-6. PMID:17398292 doi:10.1016/S0140-6736(07)60505-4 